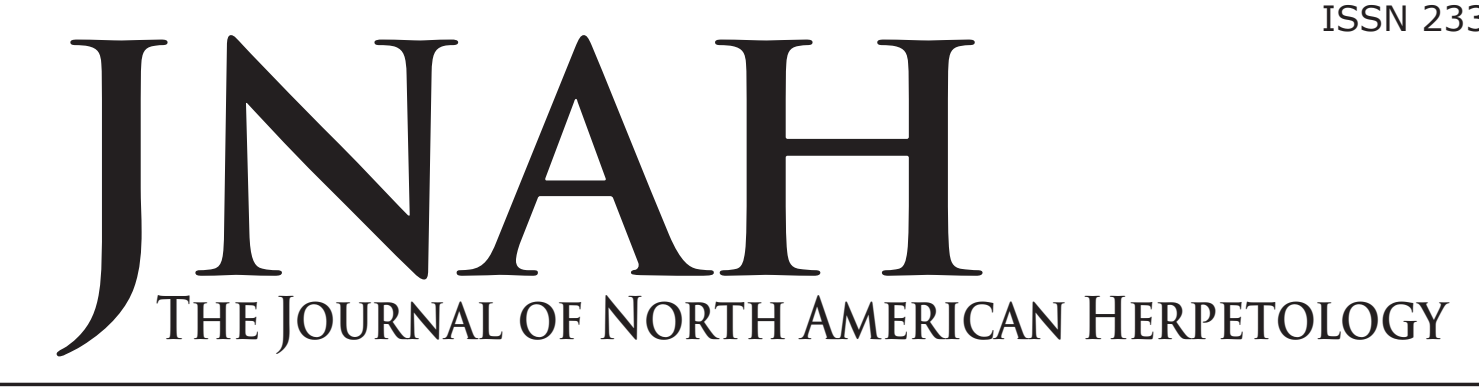
Volume 2017(1): 11-18
29 March 2017
jnah.cnah.org

\section{NOCTURNAL ARBOREALITY IN SNAKES IN THE SWAMPLANDS OF THE ATCHAFALAYA BASIN OF SOUTH-CENTRAL LOUISIANA AND BIG THICKET NATIONAL PRESERVE OF SOUTHEAST TEXAS}

\author{
BRAD M. GLORIOSO ${ }^{1,2}$ AND J. HARDIN WADDLE ${ }^{1}$ \\ ${ }^{1}$ U.S. Geological Survey, Wetland and Aquatic Research Center, 700 Cajundome Blvd., Lafayette, LA 70506, USA
${ }^{2}$ Corresponding author: gloriosob@usgs.gov
}

ABSTRACT - The southeastern United States is home to a diverse assemblage of snakes, but only one species, the Rough Greensnake (Opheodrys aestivus), is considered specialized for a predominantly arboreal lifestyle. Other species, such as Ratsnakes (genus Pantherophis) and Ribbonsnakes/ Gartersnakes (genus Thamnophis), are widely known to climb into vegetation and trees. Some explanations given for snake climbing behavior are foraging, thermoregulation, predator avoidance, and response to flood. Reports of arboreality in snake species typically not associated with life in the trees (such as terrestrial, aquatic, and even fossorial species) usually come from single observations, with no knowledge of prevalence of the behavior. Here, we report on arboreality of snake species detected during 8 years of night surveys in the Atchafalaya Basin of south-central Louisiana and 5+ years of night surveys in Big Thicket National Preserve in southeast Texas. We recorded a total of 1,088 detections of 19 snake species between the two study areas, with 348 detections above ground level (32\%). The Rough Greensnake and Western Ribbonsnake (Thamnophis proximus) accounted for nearly $75 \%$ of total arboreal detections among the two study areas. However, with one exception, all snake species detected more than once between both study areas had at least one arboreal detection. These observations demonstrate that snakes with widely varying natural histories may be found in the trees at night, and for some species, this behavior may be more common than previously believed.

\section{INTRODUCTION}

Like many things in the natural world, arboreality in snakes exists in a continuum (Lillywhite and Henderson 1993). There are bona fide tree snakes that confine all of their activities to the vegetation above ground. These snakes are most common in the tropics, and typically exhibit large eyes, slender bodies, long prehensile tails, and remarkable camouflage (Lillywhite and Henderson 1993). On the other side of the spectrum, there are decidedly terrestrial or aquatic snake species with poor climbing ability that are rarely found off of the ground. Then there are snake species that are intermediate in their use of arboreal situations, sometimes referred to as semi-arboreal species, which may use both habitats efficiently for different purposes, possibly following regular diel or seasonal patterns (Lillywhite and Henderson 1993). Still other terrestrial or aquatic snake species may ascend vegetation, sometimes at great heights, either sporadically or opportunistically (Lillywhite and Henderson 1993; Sajdak 2010). Even fossorial snakes have been known to climb occasionally (e.g. Stidham 2001; Olsen and Lee 2007; Langford and Janovy 2011).

Snake species that are typically associated with aquatic, terrestrial, or fossorial habitats may be driven to ascend into the trees for various reasons. Snakes may climb into trees to exploit seasonally available food sources. For instance, large colubrid snakes in the United States often forage in trees each spring as they seek bird eggs and chicks as prey (e.g. Cunningham 1955; Mullin et al. 2000; Sajdak 2010). Copperheads (Agkistrodon contortrix) are known to climb to prey upon seasonally abundant cicadas (Gloyd and Conant 1990; Beaupre and Roberts 2001; Sajdak 2010). Snakes may climb into trees to avoid terrestrial predators (Martins 1993; Sajdak 2010). The North American Racer, Coluber constrictor, is well documented to flee into trees to avoid capture (Conant and Collins 1998; Mitchell et al. 2000; Sajdak 2010). In Amazonian forests, many diurnal snake species, even categorically terrestrial species, were found at night sleeping on low vegetation, perhaps in avoidance of terrestrial predators (Dixon and Soini 1986; Martins 1993). Snakes may ascend into trees for better basking sites and shelter (Brown 1992; Sajdak 2010). For example, in Canada, hundreds of Red-sided Gartersnakes (Thamnophis sirtalis parietalis) were observed ascending into low trees during the day when thermal reversals caused by rain showers caused the ground to have lower temperatures than what was available in the trees (Shine 
et al. 2005). The motivations of snake climbing behavior from other reports may be related to courtship or ecdysis (e.g. Galbraith 2001; Rudolph et al. 2004; Bartz and Sajdak 2004; Gray 2009).

The Rough Greensnake, Opheodrys aestivus, is the only truly arboreal species in snake assemblages in the southeastern United States. In addition, the semi-arboreal habits of Ratsnakes (Pantherophis) and Gartersnakes/ Ribbonsnakes (Thamnophis) are well known (e.g. Tinkle 1957; Jackson 1976; Leonard and Leonard 1996; Mullin and Cooper 2002; Shine et al. 2005). There are reports of arboreality in other snake species from the southeastern United States, but these are usually based on one or few observations at one point in time with little or no data on how prevalent the behavior is in a population (e.g. Mitchell et al. 2000; Beaupre and Roberts 2001; Cupp et al. 2012; but see Avila-Villegas 2008; Graham 2013). Here, we report on arboreality of snake species detected during 8 years of night surveys in the Atchafalaya Basin of south-central Louisiana and $5+$ years of night surveys in Big Thicket National Preserve in southeast Texas. We include data on relative rates of arboreality by species, perch heights, lengths of snakes found in arboreal situations, and the surfaces on which snakes were observed.

\section{MATERIALS AND METHODS}

Study Area - We conducted our study in the Atchafalaya Basin of south-central Louisiana (2008-2015), and the Big Thicket National Preserve in southeastern Texas (20102015). The two study areas are of similar latitude and separated by about $230 \mathrm{~km}$ (Figure 1). The Atchafalaya

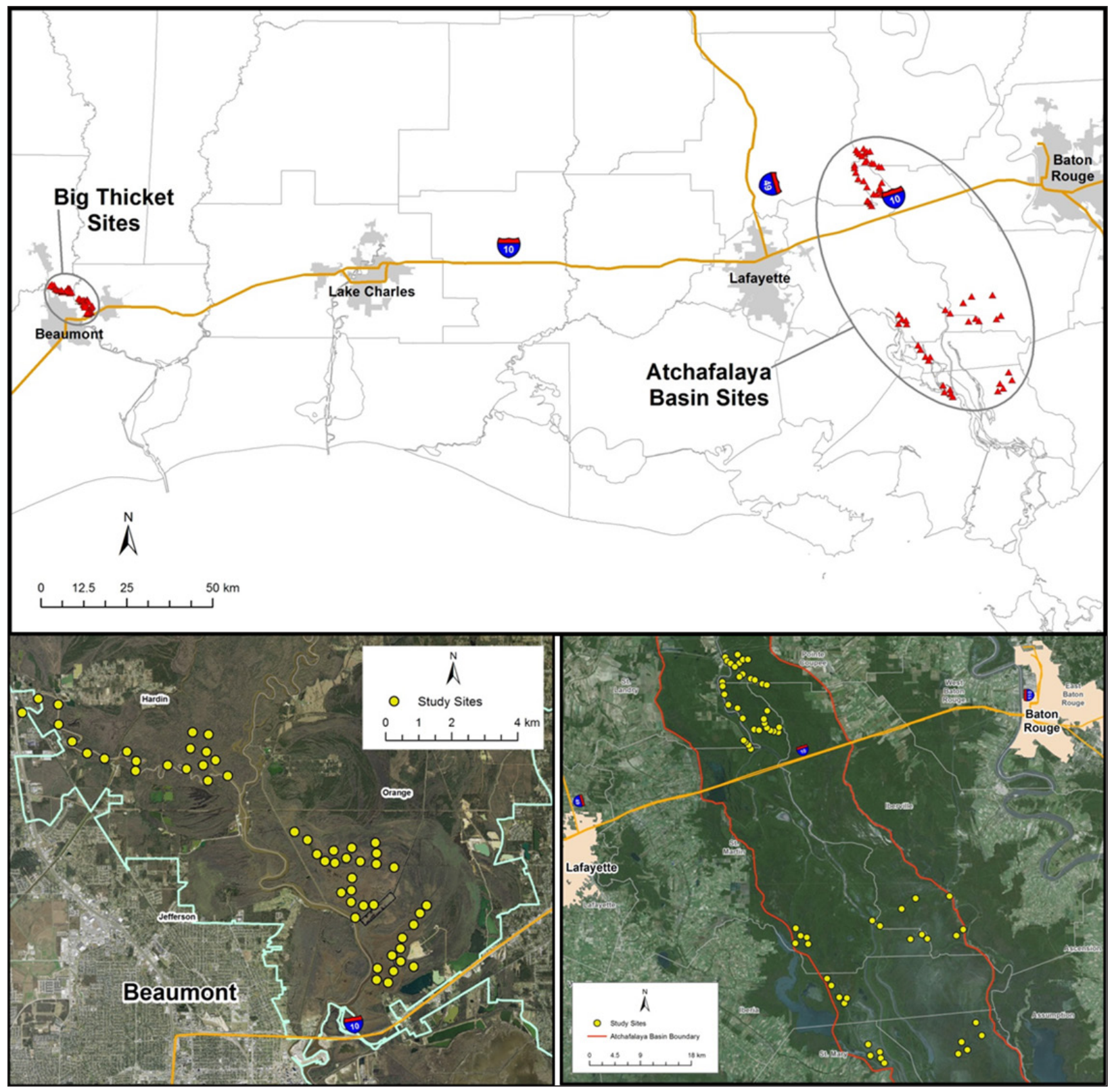

Figure 1. Map of the study sites within the two study areas, showing their similar latitudes and relative distances from one another (top). Study sites are also shown over aerial imagery at both Big Thicket National Preserve in Texas (bottom left) and the Atchafalaya Basin of south-central Louisiana (bottom right) to show general habitats. 
Basin encompasses 339,100 ha of bottomland hardwoods, forested wetlands, bayous, and back-water lakes (Piazza 2014). The original extent of the Atchafalaya Basin was likely double that of today's estimate, but the boundaries were changed after the Great Mississippi River Flood of 1927, when the East and West Atchafalaya Protection Levees were built to eliminate catastrophic flood loss (Piazza 2014). The National Park Service manages over 40,000 ha of public land at Big Thicket National Preserve, which represents a small fraction of the estimated 405,000-810,000 ha original extent of the Big Thicket (Parks and Cory 1936; Cozine 2004). The Big Thicket of southeastern Texas is known for its dense forests and high biodiversity, but much of the area was heavily logged in the $19^{\text {th }}$ and $20^{\text {th }}$ centuries (Cozine 2004).

Study Sites - In the Atchafalaya Basin, there were a total of 70 sites, with 40 sites accessible by truck occurring north of Interstate 10 (hereafter I-10) in the Sherburne Wildlife Management Area, Atchafalaya National Wildlife Refuge, and Indian Bayou areas, and 30 sites accessible only by boat occurring on state lands and the Attakapas Wildlife Management Area south of I-10 (Figure 1). Six of the northern Atchafalaya sites were suspended after 2008 (these sites are not depicted in Figure 1), but the remaining 34 sites were surveyed 4-6 times every year from 2008-2015. Fourteen sites were added mid-season in the southern Atchafalaya Basin in 2008, and 16 more were added before surveys began in 2009. All 30 southern Atchafalaya sites were surveyed 4-6 times from 20092013, after which surveys in that area were suspended. The hydrology at sites in the northern Atchafalaya Basin is primarily influenced by local rainfall, as inner levees prevent river water from spreading out over the floodplain until it reaches near I-10. The hydrology at southern sites, however, is influenced primarily by Mississippi River water levels, and can fluctuate in backwater areas from 2-3 m within a typical season, with higher pulses during floods (USGS, unpubl. data). Northern sites contained mixed hardwoods, with cypress-tupelo near wetlands, whereas southern sites were mostly cypress-tupelowillow, with some mixed hardwoods along higher spoils.

In the Big Thicket National Preserve, there were 52 total sites, all along tributaries of the Neches River near Beaumont, Texas, with 32 southern sites occurring along Lake Bayou and 10-Mile Creek, and 20 northern sites in Cooks Lake and along Pine Island Bayou (Figure 1). The southern sites were surveyed once in 2010, and 4-6 times from 2011-2015. The northern sites were added mid-season in 2012, and were surveyed 4-6 times from 2013-2015. Separating our southern and northern sites is a saltwater barrier, a permanent gated structure across the Neches River that protects the freshwater supply to the people and industry of southeast Texas. Historically, freshwater flows and natural bars at the mouth of the Neches River at Sabine Pass prevented saltwater from the Gulf of Mexico from moving upstream. However, around the turn of the century, the excavation of larger channels in several places between Sabine Pass and Beaumont for commerce provided a pathway for the heavier saltwater to migrate upstream during low freshwater flow periods. The forests at our sites were predominantly cypresstupelo, with some hardwoods at drier sites, and some pines along the higher spoils.

Survey Methods - The Atchafalaya Basin and Big Thicket studies were initiated to perform long term monitoring of amphibian populations, specifically anurans. As such, the survey methods were tailored to optimize anuran detections within a site. With the aid of powerful headlamps, nighttime visual encounter surveys (VES), which included searching under cover objects, were the sole means by which snakes were observed during surveys at both study areas. There were typically two searchers per survey, where one person would generally focus on ground searching while the other would search the vegetation and trees. We surveyed a subset of sites each night beginning 30 minutes after sunset and usually ending before 1:00 a.m. Surveys were both time and spatially constrained. In the Atchafalaya Basin, we initially performed 1 person-hr VES at each site, but by mid-2010 this was changed to 20-min surveys. We performed 10min VES surveys at Big Thicket sites because there was less search area compared to Atchafalaya sites. Surveys each year generally began in February and ended in
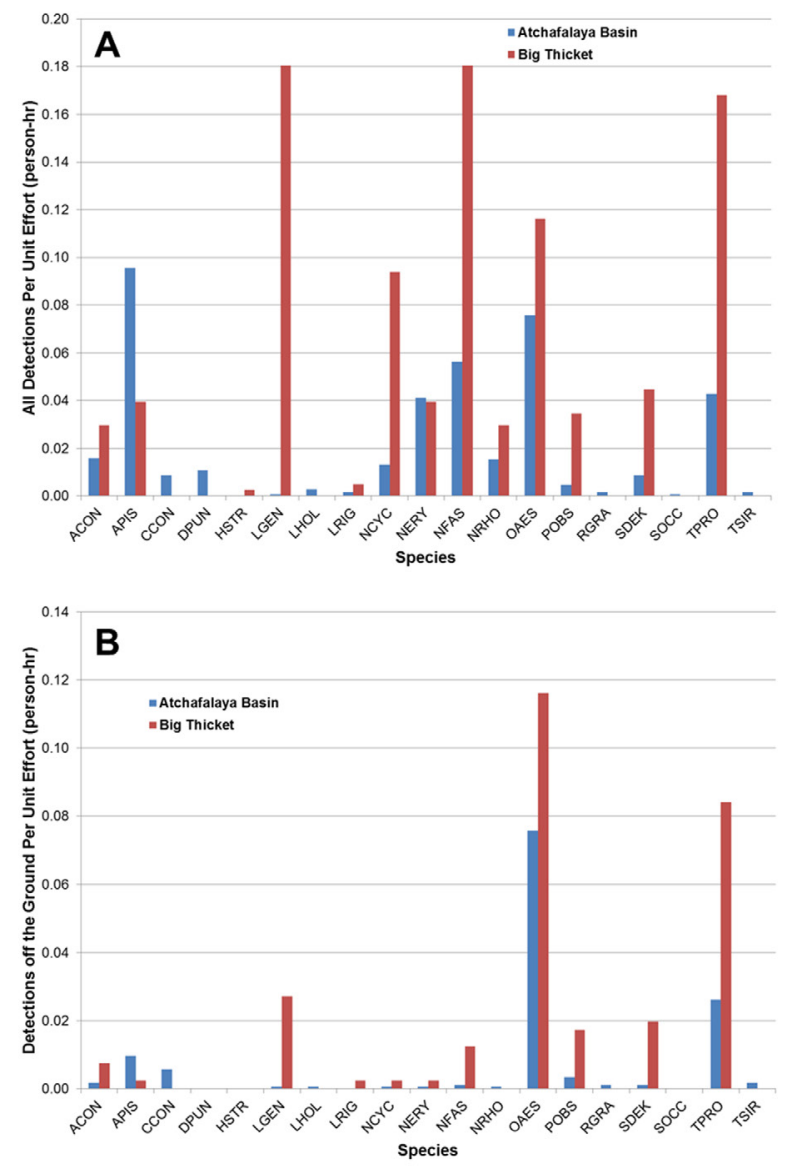

Figure 2. Detections per unit effort (person-hr) by species and study area for total snake observations $(A)$ and for snake observations off of the ground (B). Taxonomic codes: (ACON) Agkistrodon contortrix, Copperhead; (APIS) Agkistrodon piscivorus, Cottonmouth; (CCON) Coluber constrictor, North American Racer; (DPUN) Diadophis punctatus, Ring-necked Snake; (HSTR) Haldea striatula, Rough Earthsnake; (LGEN), Lampropeltis gentilis Western Milksnake; (LHOL) Lampropeltis holbrooki, Speckled Kingsnake; (LRIG) Liodytes rigida, Glossy Swampsnake; (NCYC) Nerodia cyclopion, Mississippi Green Watersnake; (NERY) Nerodia erythrogaster, Plain-bellied Watersnake; (NFAS) Nerodia fasciata, Southern Watersnake; (NRHO) Nerodia rhombifer, Diamond-backed Watersnake; (OAES) Opheodrys aestivus, Rough Greensnake; (POBS) Pantherophis obsoletus, Western Ratsnake; (RGRA) Regina grahamii, Graham's Crayfish Snake; (SDEK) Storeria dekayi Dekay's Brownsnake; (SOCC) Storeria occipitomaculata, Red-bellied Snake; (TPRO) Thamnophis proximus, Western Ribbonsnake (TSIR) Thamnophis sirtalis, Common Gartersnake. 
Table 1. The total number of snakes detected, and the number and percentage of snakes detected off of the ground in both the Atchafalaya Basin and Big Thicket study areas. Dashes indicate that a species was not observed in that study area.

\begin{tabular}{|c|c|c|c|c|c|c|}
\hline Species & \# detected & $\begin{array}{l}\text { ATCHAFALAYA } \\
\text { \# off ground }\end{array}$ & $\begin{array}{l}\text { ASIN } \\
\% \text { off ground }\end{array}$ & \# detected & $\begin{array}{l}\text { BIG THICKET } \\
\text { \# off ground }\end{array}$ & $\%$ off ground \\
\hline Agkistrodon contortrix & 28 & 3 & 10.71 & 12 & 3 & 25.00 \\
\hline Agkistrodon piscivorus & 168 & 17 & 10.12 & 16 & 1 & 6.25 \\
\hline Coluber constrictor & 15 & 10 & 66.67 & - & - & - \\
\hline Diadophis punctatus & 19 & 0 & 0.00 & - & - & - \\
\hline Haldea striatula & - & - & - & 1 & 0 & 0.00 \\
\hline Lampropeltis gentilis & 1 & 1 & 100.00 & 73 & 11 & 15.07 \\
\hline Lampropeltis holbrooki & 5 & 1 & 20.00 & - & - & - \\
\hline Liodytes rigida & 3 & 0 & 0.00 & 2 & 1 & 50.00 \\
\hline Nerodia cyclopion & 23 & 1 & 4.35 & 38 & 1 & 2.63 \\
\hline Nerodia erythrogaster & 72 & 1 & 1.39 & 16 & 1 & 6.25 \\
\hline Nerodia fasciata & 99 & 2 & 2.02 & 73 & 5 & 6.85 \\
\hline Nerodia rhombifer & 27 & 1 & 3.70 & 12 & 0 & 0.00 \\
\hline Opheodrys aestivus & 133 & 133 & 100.00 & 47 & 47 & 100.00 \\
\hline Pantherophis obsoletus & 8 & 6 & 75.00 & 14 & 7 & 50.00 \\
\hline Regina grahamii & 3 & 2 & 66.67 & - & - & - \\
\hline Storeria dekayi & 15 & 2 & 13.33 & 18 & 8 & 44.44 \\
\hline Storeria occipitomaculata & 1 & 0 & 0.00 & - & - & - \\
\hline Thamnophis proximus & 75 & 46 & 61.33 & 68 & 34 & 50.00 \\
\hline Thamnophis sirtalis & 3 & 3 & 100.00 & - & - & - \\
\hline
\end{tabular}

August at both study areas, but small deviations from this occurred in some years. Weather data, including air temperature, were recorded at each survey.

During surveys for anurans, other amphibians and reptiles, including the snakes discussed here, were noted when observed at a site. Upon detecting a snake at a study site, we determined the species, noted the surface on which the snake was found, and estimated the height where the snake was first observed. For nonvenomous snakes, capture was usually attempted, and if captured, snout-vent length was measured using a collapsible rule to the nearest $\mathrm{mm}$. Because the study was aimed at amphibians, detailed information on snake behavior was not recorded, but some general patterns were noted.

\section{RESULTS AND DISCUSSION}

A total of 1,088 snake observations of 19 species were made during night surveys of the Atchafalaya Basin ( $\mathrm{N}=$ 698) and Big Thicket National Preserve ( $N=390$; Table

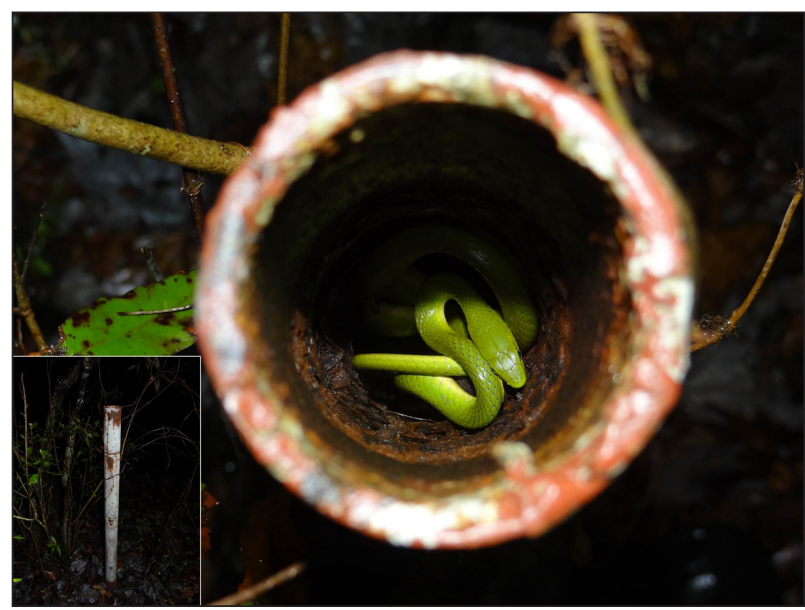

Figure 3. In situ Rough Greensnake, Opheodrys aestivus, found coiled in vertical steel pipe about $90 \mathrm{~cm}$ high in the Atchafalaya Basin on 11 March 2015. On 1 June 2015, this same pipe contained a Rough Greensnake at about the same height, presumably the same individual
1). Total survey effort for all years combined was 1755.9 and 404.5 person-hrs in the Atchafalaya Basin and Big Thicket, respectively. Higher snake detection rates were observed for nearly all species at Big Thicket compared to the Atchafalaya Basin (Figure 2A). Though a few species approached 0.2 snakes/person-hr at Big Thicket, most snake species at both study areas had rates less than 0.05 snakes/person-hr (Figure 2A). When considering only arboreal detections, rates were below 0.03 snakes/ person-hr for all species at both study areas with three exceptions (Rough Greensnakes at both study areas and Western Ribbonsnakes at Big Thicket) (Figure 2B).

Of 1,088 total snake observations, 348 were made off of the ground $(31.99 \%)$ (Table 1$)$. The two study areas had similar percentages of snakes observed off of the ground at $32.81 \%$ for the Atchafalaya Basin and 30.51\% for Big Thicket. Rough Greensnakes accounted for 180 combined detections, $100 \%$ of which were off of the ground. Removing greensnakes from the totals, $16.99 \%$ and $20.99 \%$ of snake detections in the Atchafalaya Basin and Big Thicket occurred off of the ground, respectively.

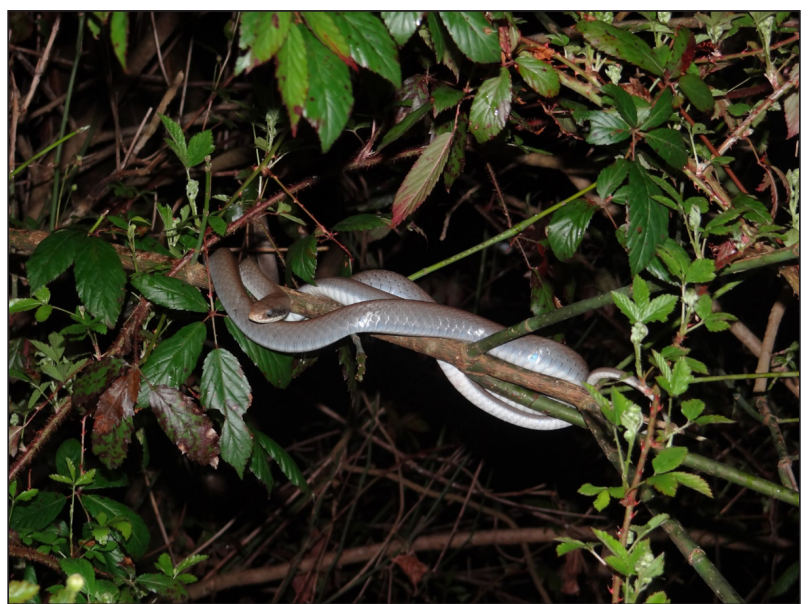

Figure 4. In situ Coluber constrictor latrunculus, Black-masked Racer, observed at rest ca. $150 \mathrm{~cm}$ off the ground in a small tree in the Atchafalaya Basin on 12 March 2015. 
Table 2. The mean height $(\mathrm{cm})$ and ranges of snakes detected with a minimum of one capture off of the ground in the Atchafalaya Basin and Big Thicket study areas. Dashes indicate that a species was not observed in that study area. Measurement in centimeters $(\mathrm{cm})$.

\begin{tabular}{|c|c|c|c|c|c|c|}
\hline \multirow[b]{2}{*}{ Species } & \multicolumn{3}{|c|}{ ATCHAFALAYA BASIN } & \multicolumn{3}{|c|}{ BIG THICKET } \\
\hline & \# off ground & Mean Height & Height Range & \# off ground & Mean Height & Height Range \\
\hline Agkistrodon contortrix & 3 & 70 & $30-100$ & 3 & 147 & $10-350$ \\
\hline Agkistrodon piscivorus & 17 & 60 & $5-200$ & 1 & 10 & \\
\hline Coluber constrictor & 10 & 254 & $150-450$ & - & - & 一 \\
\hline Lampropeltis gentilis & 1 & 40 & & 11 & 85 & $10-180$ \\
\hline Lampropeltis holbrooki & 1 & 70 & & - & - & - \\
\hline Liodytes rigida & 0 & & & 1 & 40 & \\
\hline Nerodia cyclopion & 1 & 10 & & 1 & 100 & \\
\hline Nerodia erythrogaster & 1 & 100 & & 1 & 50 & \\
\hline Nerodia fasciata & 2 & 150 & $150-150$ & 5 & 44 & $10-60$ \\
\hline Nerodia rhombifer & 1 & 400 & & - & - & - \\
\hline Opheodrys aestivus & 133 & 249 & $30-600$ & 47 & 213 & $40-600$ \\
\hline Pantherophis obsoletus & 6 & 312 & $120-600$ & 7 & 156 & $20-350$ \\
\hline Regina grahamii & 2 & 210 & $200-220$ & - & - & - \\
\hline Storeria dekayi & 2 & 235 & $220-250$ & 8 & 116 & $5-350$ \\
\hline Thamnophis proximus & 46 & 201 & $20-500$ & 34 & 114 & $5-300$ \\
\hline Thamnophis sirtalis & 3 & 168 & $155-180$ & - & - & - \\
\hline
\end{tabular}

Western Ribbonsnakes accounted for $47.9 \%$ and $47.2 \%$ of the remaining detections in the Atchafalaya Basin and Big Thicket, respectively. Some snake species observed only occasionally, such as North American Racers ( $\mathrm{N}=$ 15) and Western Ratsnakes (Pantherophis obsoletus; $\mathrm{N}=$ 22), were observed in arboreal situations more times than not (Table 1). Some species, particularly watersnakes (Nerodia spp.), were detected relatively often but were rarely observed off of the ground. With the exception of Ring-necked Snakes (Diadophis punctatus), all snake species detected more than once between both study areas had a minimum of one arboreal detection.

Of species with greater than five detections off of the ground, mean height was over $2 \mathrm{~m}$ for four species in the Atchafalaya Basin and one species in Big Thicket (Table 2). Nine species were found at least $2 \mathrm{~m}$ off of the ground at least once. The maximum observed perch height of any snake was approximately $6 \mathrm{~m}$ (for Rough Greensnakes in both study areas and Western Ratsnakes in the Atchafalaya Basin). Greensnakes were observed between $1.1-4.0 \mathrm{~m}$ on $75.0 \%$ and $89.3 \%$ of detections in the Atchafalaya Basin and Big Thicket, respectively (Table 3). Overall, perch heights for greensnakes in this study match very closely with a detailed study from Arkansas

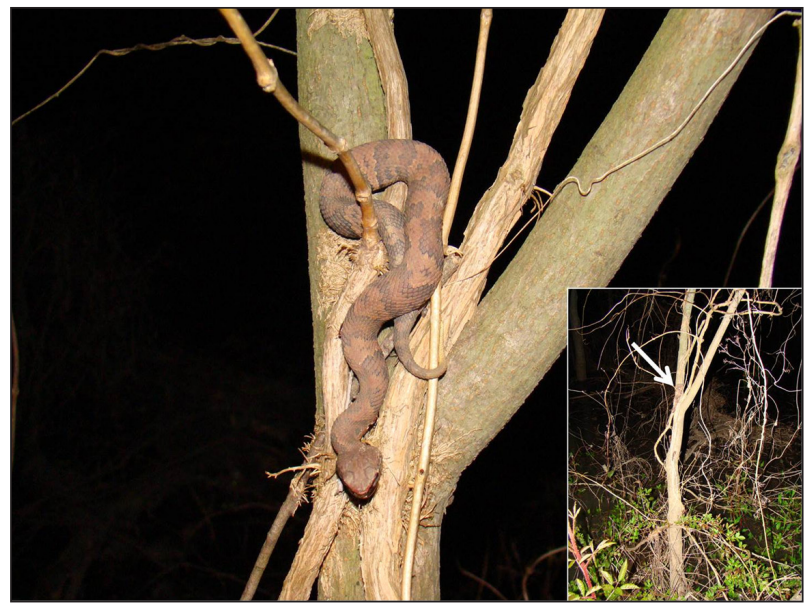

Figure 5. In situ juvenile Cottonmouth, Agkistrodon piscivorus, found 17 March $2011 \mathrm{ca} .100 \mathrm{~cm}$ off the ground in a small tree at a flooded site in the southern Atchafalaya Basin.
(Plummer 1981; Table 3). There was no clear indication that juveniles were more or less likely to be observed off of the ground among or within species, as most species had both small and large individuals observed in arboreal situations (Table 4). Most observations occurred during warmer surveys, but greensnakes were a notable exception, with observations below $7^{\circ} \mathrm{C}$ in both study areas (Table 5). Trees, shrubs, and vines were the most common surfaces on which snakes were found off of the ground (Table 6). Coarse woody debris was primarily used by lower-perched Cottonmouths (Agkistrodon piscivorus) and Western Milksnakes. In an unusual situation, the same hollow open-topped vertical steel pipe was used in the Atchafalaya Basin by presumably the same greensnake on two surveys nearly 3 months apart, where it was found on both occasions squeezed within the pipe nearly a meter high above the ground (Figure 3 ).

Though detailed snake behavior was not recorded, some generalizations can be made. Some species, such as the strictly diurnal North American Racer and Rough Greensnake, were never initially observed active at night in arboreal situations, though one racer was found terrestrially actively shedding its skin on the roadside grass. Mitchell et al. (2000) observed a North American Racer $3 \mathrm{~m}$ high in a maple tree at the end of the day, where it remained motionless for an hour, and surmised

Table 3. The percentage of nighttime perch heights of Opheodrys aestivus at various height intervals in Arkansas (from Plummer 1981) compared to the Atchafalaya Basin of south-central Louisiana (this study) and Big Thicket National Preserve in southeast Texas (this study). Percentages were rounded to the nearest whole number; all columns total $100 \%$.

\begin{tabular}{|c|c|c|c|}
\hline \multirow[b]{2}{*}{$\begin{array}{l}\text { Perch } \\
\text { Height }\end{array}$} & \multicolumn{3}{|c|}{ Opheodrys aestivus } \\
\hline & $\begin{array}{c}\% \text { detected } \\
\text { Plummer } 1981 \\
n=200\end{array}$ & $\begin{array}{c}\text { \% detected } \\
\text { Atchafalaya } \\
n=132\end{array}$ & $\begin{array}{c}\% \text { detected } \\
\text { Big Thicket } \\
n=47\end{array}$ \\
\hline $0.0-1.0$ & 14 & 14 & 9 \\
\hline $1.1-2.0$ & 40 & 28 & 47 \\
\hline $2.1-3.0$ & 21 & 36 & 32 \\
\hline $3.1-4.0$ & 12 & 11 & 11 \\
\hline $4.1-5.0$ & 7 & 9 & 0 \\
\hline$>5.0$ & 6 & 2 & 2 \\
\hline
\end{tabular}


Table 4. The mean snout-vent lengths (SVL) and ranges of snake species with a minimum of one capture off of the ground in the Atchafalaya Basin and Big Thicket study areas. Dashes indicate that a species was not observed in that study area.

\begin{tabular}{|c|c|c|c|c|c|c|c|}
\hline \multirow[b]{2}{*}{ Species } & \multirow[b]{2}{*}{$\begin{array}{l}\text { \# off } \\
\text { ground }\end{array}$} & \multicolumn{2}{|c|}{ ATCHAFALAYA BASIN } & \multicolumn{4}{|c|}{ BIG THICKET } \\
\hline & & $\begin{array}{c}\text { \# with } \\
\text { SVL }\end{array}$ & $\begin{array}{r}\text { Mean SVL SVL Range } \\
(\mathrm{mm})\end{array}$ & $\begin{array}{r}\text { \# off } \\
\text { ground }\end{array}$ & $\begin{array}{r}\text { \#with } \\
\text { SVL }\end{array}$ & $\begin{array}{r}\text { Mean SVL } \\
(\mathrm{mm})\end{array}$ & $\begin{array}{r}\text { SVL Range } \\
(\mathrm{mm})\end{array}$ \\
\hline
\end{tabular}

Coluber constrictor

Lampropeltis gentilis

Lampropeltis holbrooki

Liodytes rigida

Nerodia cyclopion

Nerodia erythrogaster

Nerodia fasciata

Opheodrys aestivus

Pantherophis obsoletus

Regina grahamii

Storeria dekayi

Thamnophis proximus

Thamnophis sirtalis

$\begin{array}{rr}10 & 10 \\ 1 & \\ 1 & \\ - & \\ 1 & \\ 2 & \\ 133 & 12 \\ 6 & \\ 2 & \\ 2 & \\ 46 & \\ 3 & \end{array}$

$\begin{array}{rr}935 & 592-1112 \\ 460 & \\ 450 & \\ - & - \\ 805 & \\ 433 & \\ 292 & 253-330 \\ 337 & 159-503 \\ 785 & 391-1450 \\ 730 & 660-800 \\ 300 & 263-337 \\ 442 & 170-722 \\ 506 & 384-620\end{array}$

$\begin{array}{rr}- & \\ -11 & \\ 1 & \\ 1 & \\ 1 & \\ 5 & \\ 47 & \\ 7 & \\ - & \\ 8 & \\ 34 & \\ - & \end{array}$

-
11
1
1
1
4
45
7
-
8
31
-

$\begin{array}{rr}- & - \\ 423 & 263-575 \\ - & - \\ 420 & \\ 513 & \\ 385 & \\ 383 & 318-466 \\ 383 & 206-568 \\ 876 & 311-1320 \\ - & - \\ 261 & 182-320 \\ 449 & 187-725 \\ - & -\end{array}$

that racers may ascend trees at the end of the day to rest, perhaps through the night. Our observations of inactive arboreal racers throughout the first half of the night support this behavior (Figure 4). Other species, such as cottonmouths, watersnakes, ratsnakes, and ribbonsnakes, were rarely found active in arboreal situations at night, but often were found terrestrially active. DeGregorio et al. (2014) experimentally showed that ratsnakes (Pantherophis) were successful foragers in both low and high light using visual and chemical cues, whereas racers (Coluber) were nearly exclusively diurnal regardless of temperature. They posited that the ability of ratsnakes to be facultatively nocturnal should buffer them and similarly plastic species from climate change.

Other species, such as copperheads, milksnakes, and the typically fossorial Dekay's Brownsnake (Storeria dekayi), were often found active at night both in terrestrial and arboreal situations. We observed copperheads preying upon cicadas from a low-hanging tree branch in Big Thicket. Copperheads are known predators of cicadas, and they are known to climb high to reach them, up to 13 m (Sajdak 2010; Beaupre and Roberts 2001). Milksnakes were often found active terrestrially, and though some observations were of individuals ascending small saplings, most observations of them in arboreal situations were

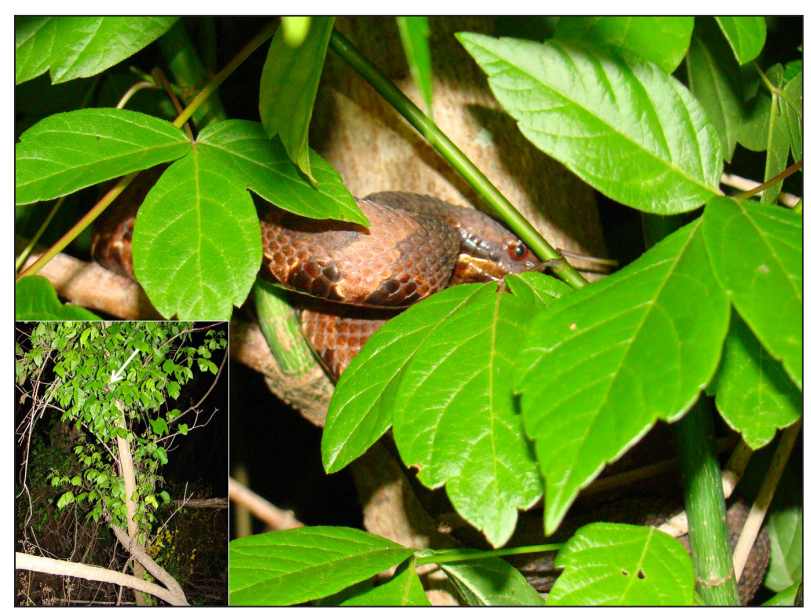

Figure 6. In situ juvenile Cottonmouth, Agkistrodon piscivorus, found 6 April $2009 \mathrm{ca}$. $200 \mathrm{~cm}$ off the ground in a small tree at a flooded site in the southern Atchafalaya Basin.

within perched logs or under bark. For example, just before midnight on April 17, 2013, we observed a pair of milksnakes mating while sticking out slightly from under the bark on top of a fallen tree. On April 14, 2015, four of the eight total arboreal brownsnake observations at Big Thicket were made at three different sites. Brownsnakes have been known to arboreally bask during the day (Brown 1992; Gibson et al. 2005), but that would not account for these nighttime ascents into trees. Cupp et al. (2012) speculated that their observation of four adult individuals of the congener Red-bellied Snake (S. occipitomaculata) observed in close proximity to each other was a mating aggregation. Our observation on this night was at three different sites, and the two individuals found at one site were not in close proximity to each other. We did observe, however, that one of the four brownsnakes on that night was actively climbing vegetation towards a slug on the trunk of a small sapling. There was an abundance of slugs on the vegetation that night that may have prompted brownsnakes to climb to exploit this resource.

We found cottonmouths off the ground at much higher rates than the $0.25 \%$ reported by Graham (2013) from both day and night observations from a 7-yr dataset from Alabama and Georgia. Part of the reason for this may be due to the flood pulses observed in the southern Atchafalaya

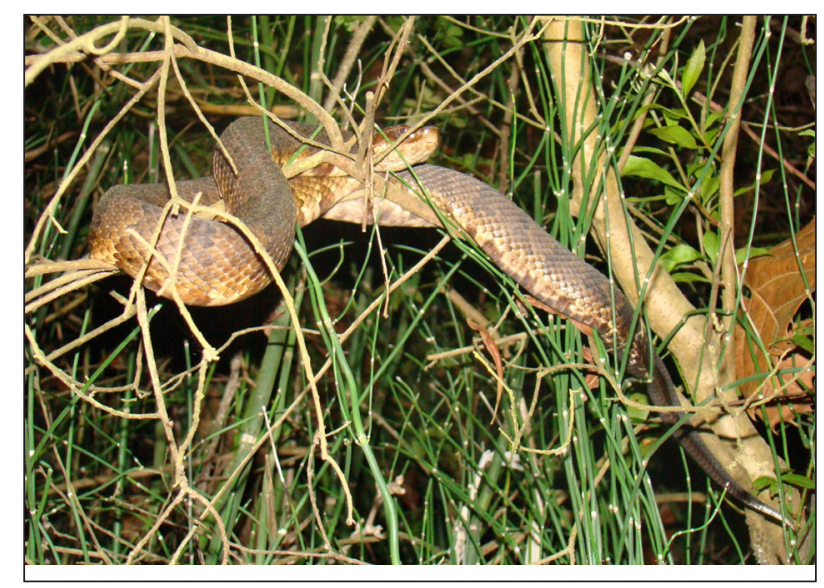

Figure 7. In situ adult Cottonmouth, Agkistrodon piscivorus, found 29 February $2012 \mathrm{ca} .180 \mathrm{~cm}$ off the ground on some small branches among horsetail at a non-flooded site on the higher berm beside a bayou in the southern Atchafalaya Basin. 
Table 5. The mean air temperature $\left({ }^{\circ} \mathrm{C}\right)$ and ranges when snake species with a minimum of one capture off of the ground were observed in the Atchafalaya Basin and Big Thicket study areas. Dashes indicate that a species was not observed in that study area.

\begin{tabular}{|c|c|c|c|c|c|c|}
\hline \multirow[b]{2}{*}{ Species } & \multicolumn{3}{|c|}{ ATCHAFALAYA BASIN } & \multicolumn{3}{|c|}{ BIG THICKET } \\
\hline & $\begin{array}{l}\text { \# off } \\
\text { ground }\end{array}$ & $\begin{array}{r}\text { Mean } \\
\text { Temp (C) }\end{array}$ & $\begin{array}{r}\text { Temp } \\
\text { Range (C) }\end{array}$ & $\begin{array}{l}\text { \# off } \\
\text { ground }\end{array}$ & $\begin{array}{r}\text { Mean } \\
\text { Temp (C) }\end{array}$ & $\begin{array}{r}\text { Temp } \\
\text { Range (C) }\end{array}$ \\
\hline Agkistrodon contortrix & 3 & 25.1 & $23.6-25.9$ & 3 & 23.2 & $22.6-24.0$ \\
\hline Agkistrodon piscivorus & 17 & 20.9 & $13.3-26.5$ & 1 & 22.3 & \\
\hline Coluber constrictor & 10 & 23.0 & $15.7-26.6$ & - & - & - \\
\hline Lampropeltis gentilis & 1 & 21.7 & & 11 & 22.9 & $15.7-27.5$ \\
\hline Lampropeltis holbrooki & 1 & 26.3 & & - & - & - \\
\hline Liodytes rigida & - & - & - & 1 & 21.1 & \\
\hline Nerodia cyclopion & 1 & 27.8 & & 1 & 27.3 & \\
\hline Nerodia erythrogaster & 1 & 24.5 & & 1 & 25.5 & \\
\hline Nerodia fasciata & 2 & 16.5 & $13.0-19.9$ & 5 & 27.0 & $25.7-27.9$ \\
\hline Nerodia rhombifer & 1 & 18.5 & & - & - & - \\
\hline Opheodrys aestivus & 133 & 20.4 & $6.1-29.4$ & 47 & 21.8 & $6.9-28.8$ \\
\hline Pantherophis obsoletus & 6 & 21.8 & $18.3-25.1$ & 7 & 24.2 & $21.1-29.5$ \\
\hline Regina grahamii & 2 & 21.0 & $18.5-23.5$ & - & - & - \\
\hline Storeria dekayi & 2 & 21.7 & $18.5-24.8$ & 8 & 22.6 & $20.4-26.1$ \\
\hline Thamnophis proximus & 46 & 23.5 & $15.4-27.0$ & 34 & 23.7 & $17.9-29.9$ \\
\hline Thamnophis sirtalis & 3 & 22.9 & $20.9-25.5$ & - & - & - \\
\hline
\end{tabular}

Table 6. The location observed of snake species with a minimum of one capture off of the ground in the Atchafalaya Basin and Big Thicket study areas combined.

\begin{tabular}{|c|c|c|c|c|c|c|}
\hline \multirow[b]{3}{*}{ Species } & \multicolumn{5}{|c|}{ ATHCFALAYA BASIN \& BIG THICKET COMBINED } & \multirow{3}{*}{$\begin{array}{l}\text { In Logs } \\
\text { or Pipes }\end{array}$} \\
\hline & \# off & Shrub & & Coarse & Herbaceous & \\
\hline & & or Tree & Vine & Woody Debris & Vegetation & \\
\hline Agkistrodon contortrix & 6 & 5 & 0 & 1 & 0 & 0 \\
\hline Agkistrodon piscivorus & 18 & 5 & 1 & 11 & 1 & 0 \\
\hline Coluber constrictor & 10 & 8 & 2 & 0 & 0 & 0 \\
\hline Lampropeltis gentilis & 12 & 5 & 1 & 4 & 0 & 2 \\
\hline Lampropeltis holbrooki & 1 & 1 & 0 & 0 & 0 & 0 \\
\hline Liodytes rigida & 1 & 1 & 0 & 0 & 0 & 0 \\
\hline Nerodia cyclopion & 2 & 0 & 0 & 1 & 1 & 0 \\
\hline Nerodia erythrogaster & 2 & 0 & 0 & 1 & 1 & 0 \\
\hline Nerodia fasciata & 7 & 3 & 1 & 2 & 0 & 1 \\
\hline Nerodia rhombifer & 1 & 1 & 0 & 0 & 0 & 0 \\
\hline Opheodrys aestivus & 180 & 112 & 47 & 1 & 18 & 2 \\
\hline Pantherophis obsoletus & 13 & 11 & 1 & 1 & 0 & 0 \\
\hline Regina grahamii & 2 & 2 & 0 & 0 & 0 & 0 \\
\hline Storeria dekayi & 10 & 3 & 4 & 0 & 2 & 1 \\
\hline Thamnophis proximus & 80 & 37 & 24 & 4 & 14 & 1 \\
\hline Thamnophis sirtalis & 3 & 0 & 2 & 0 & 1 & 0 \\
\hline
\end{tabular}

Basin sites, where, during a typical spring, many of the sites are completely inundated with water. Fifteen of 17 cottonmouth detections off of the ground in the Atchafalaya Basin occurred at these southern sites. Many of these sites were inundated when these observations occurred, likely prompting snakes to ascend onto coarse woody debris or low vegetation (Figures 5-6). As others have found for thick-bodied venomous snakes, many, but not all, of these snakes observed off of the ground were juveniles (e.g. Coupe 2001; Cobb et al. 2005; Graham 2013; Figure 7). One particular southern site, an oftenwet island in Attakapas Wildlife Management Area, was responsible for arboreal observations above the water of two cottonmouths, the sole Diamond-backed Watersnake ( $N$. rhombifer), and both Graham's Crayfish Snakes (Regina grahamii). Similarly, Eastern Ribbonsnakes ( $T$. sauritus) became almost completely arboreal at a flooded southern Alabama site (Langford et al. 2011).

Because the anurans we sought were distributed throughout the same fossorial, terrestrial, aquatic, and arboreal situations as the snakes we observed, we believe that our observations of snakes was not limited by our anuran targets. We understand detection is imperfect, and that we certainly missed snakes during surveys at our sites, but snakes in arboreal situations, small and large alike, were conspicuous at night with the aid of our powerful headlamps. Therefore, we are confident that our results accurately reflect our general findings that overall nocturnal snake detections are low for most species, with arboreal nocturnal detections very low, but widespread among snake species in our assemblages. Cunningham (1955) stated that the rather general use of arboreal habitats in southern California by amphibians and reptiles, including snakes, and their similar behavior patterns among species despite their varied morphologies and life histories, may reflect certain common factors concerned with climbing behavior. Targeted research on nocturnal arboreality and activity in snakes not typically associated with life in the trees is needed to further elucidate the motives behind such behavior within and among species.

Acknowledgements - For permitting and logistical support, we thank the Louisiana Department of Wildlife 
and Fisheries, U.S. Fish \& Wildlife Service, U.S. Army Corps of Engineers, and National Park Service. We thank T. Thigpen, S. Jones, L. Elston, J. Hefner, J. Eaker, L. Muse, and S. Godfrey for their assistance with field work, along with many others who have helped out through the years. Any use of trade, firm, or product names is for descriptive purposes only and does not imply endorsement by the U.S. Government.

\section{LITERATURE CITED}

Avila-Villegas, H. 2008. Crotalus catalinensis (Santa Catalina Island Rattlesnake). Arboreality. Herpetological Review 39:468.

Bartz, A.D. and R.A. Sajdak. 2004. Crotalus horridus (Timber Rattlesnake). Arboreality, courtship. Herpetological Review 35:61.

Beaupre, S.J. and K.G. Roberts. 2001. Agkistrodon contortrix contortrix (Southern Copperhead). Chemotaxis, arboreality, and diet. Herpetological Review 32:44-45.

Brown, E.E. 1992. Notes on the amphibians and reptiles of the western Piedmont of North Carolina. The Journal of the Elisha Mitchell Scientific Society 108:38-54.

Cobb, V.A., J.J. Green, T. Worrall, J. Pruett, and B. Glorioso. 2005. Initial den location behavior in a litter of neonate timber rattlesnakes (Crotalus horridus) using external transmitters. Southeastern Naturalist 4:723-730.

Conant, R. and J.T. Collins. 1998. A Field Guide to Reptiles and Amphibians: Eastern and Central North America. $3^{\text {rd }}$ ed. Houghton Mifflin, Boston, Massachusetts. 616 $\mathrm{pp}$.

Coupe, B. 2001. Arboreal behavior in timber rattlesnakes (Crotalus horridus). Herpetological Review 32:8385.

Cozine, J.J. 2004. Saving the Big Thicket: From Exploration to Preservation, 1685-2003. University of North Texas Press, Denton, Texas. 272 pp.

Cunningham, J.D. 1955. Arboreal habits of certain reptiles and amphibians in southern California. Herpetologica 11:217-220.

Cupp, P.V., Jr., J.P. Ritzert, D. Dourson, and J. Dourson. 2012. Storeria occipitomaculata (Red-bellied Snake). Behavior and reproduction. Herpetological Review 43:152.

DeGregorio, B.A., J.H. Sperry, D.P. Valente, and P.J. Weatherhead. 2014. Facultative nocturnal behavior in snakes: experimental examination of why and how with ratsnakes (Elaphe obsoleta) and racers (Coluber constrictor). Canadian Journal of Zoology 92:229-237.

Dixon, J.R. and P. Soini. 1986. The Reptiles of the Upper Amazon Basin, Iquitos Region, Peru. Milwaukee Public Museum, Milwaukee, Wisconsin. 154 pp.

Galbraith, D.A. 2001. Arboreal courtship behaviour by eastern garter snakes, Thamnophis sirtalis sirtalis, in September in Bruce County, Ontario. Canadian Field-Naturalist 115:347-348.

Gibson, J., P. Powell, and J.C. Mitchell. 2005. Arboreality in a northern brownsnake (Storeria dekayi dekayi) in Virginia. Banisteria 26:24-25.

Gloyd, H.K. and R. Conant. 1990. Snakes of the Agkistrodon Complex. A Monographic Review. Contributions to Herpetology 6. Society for the Study of Amphibians and Reptiles, Oxford, Ohio. $614 \mathrm{pp}$.

Graham, S. 2013. How frequently do cottonmouths (Agkistrodon piscivorus) bask in trees? Journal of
Herpetology 47:428-431.

Gray, B.S. 2009. Arboreal ecdysis in the eastern garter snake (Thamnophis sirtalis sirtalis). Journal of Kansas Herpetology 29:11.

Jackson, J.A. 1976. Relative climbing tendencies of gray (Elaphe obsoleta spiloides) and black rat snakes ( $E$. o. obsoleta). Herpetologica 32:359-361.

Langford, G.J., J.A. Borden, and D.H. Nelson. 2011. Ecology of the eastern ribbonsnake (Thamnophis sauritus) in southern Alabama with evidence of seasonal multiple broods. Herpetological Conservation and Biology 6:400-409.

Langford, G.J. and J. Janovy, Jr. 2011. Heterodon nasicus (Western Hog-nosed Snake). Diet and arboreal foraging behavior. Herpetological Review 42:291.

Leonard W.P. and N.P. Leonard. 1996. Thamnophis sirtalis pickeringii (Puget Sound Garter Snake). Foraging and arboreality. Herpetological Review 27:84.

Lillywhite, H.B. and R.W. Henderson. 1993. Behavioral and functional ecology of arboreal snakes. Pp. 1-48 In R.A. Seigel and J.T. Collins (Eds.), Snakes: Ecology and Behavior. McGraw-Hill, New York, New York.

Martins, M. 1993. Why do snakes sleep on the vegetation in central Amazonia? Herpetological Review 24:8384.

Mitchell, J.C., C.T. Georgel, and K.D. Walters. 2000. Field notes: Coluber constrictor constrictor (Northern Black Racer). Catesbeiana 20:83-84.

Mullin, S.J., W.H.N. Gutzke, G.D. Senitsky, and R.J. Cooper. 2000. Home ranges of rat snakes (Colubridae: Elaphe) in different habitats. Herpetological Review 31:20-22.

Mullin, S.J. and R.J. Cooper. 2002. Barking up the wrong tree: climbing performances of rat snakes and its implications for depredation of avian nests. Canadian Journal of Zoology 80:591-595.

Olsen, M.A. and J.R. Lee. 2007. Pituophis melanoleucus lodingi (Black Pinesnake). Tree climbing. Herpetological Review 38:210.

Parks, H.B. and V.L. Cory. 1936. Biological survey of the east Texas Big Thicket Area: The fauna and flora of the Big Thicket area. Special Publication by the Texas Academy of Sciences. Privately Published. $51 \mathrm{pp}$.

Piazza, B.P. 2014. The Atchafalaya River Basin: History and Ecology of an American Wetland. Texas A\&M University Press, College Station, Texas. 305 pp.

Plummer, M.V. 1981. Habitat utilization, diet, and movements of a temperate arboreal snake (Opheodrys aestivus). Journal of Herpetology 15:425-432.

Rudolph, D.C., R.R. Schaefer, D. Saenz, and R.N. Conner. 2004. Arboreal behavior in the timber rattlesnake, Crotalus horridus, in eastern Texas. Texas Journal of Science 56:395-404

Sajdak, R.A. 2010. Hunters in the Trees: A Natural History of Arboreal Snakes. Krieger, Malabar, Florida. $192 \mathrm{pp}$.

Shine, R., M. Wall, T. Langkilde, and R.T. Mason. 2005. Scaling the heights: thermally driven arboreality in garter snakes. Journal of Thermal Biology 30:179185.

Stidham, T.A. 2001. Diadophis punctatus (Ringneck Snake). Arboreal behavior. Herpetological Review 32:262.

Tinkle, D.W. 1957. Maturation and reproduction of Thamnophis sauritus proximus. Ecology 38:69-77. 